DOI 10.37882/2223-2982.2021.07.12

\title{
ОСОБЕННОСТИ ФОРМИРОВАНИЯ КОММУНИКАТИВНЫХ УНИВЕРСАЛЬНЫХ УЧЕБНЫХ ДЕЙСТВИЙ У МЛАДШИХ ШКОЛЬНИКОВ С ЗАДЕРЖКОЙ ПСИХИЧЕСКОГО РАЗВИТИЯ
}

\section{FEATURES OF FORMATION OF COMMUNICATIVE UNIVERSAL EDUCATIONAL ACTIONS IN YOUNGER SCHOOLS WITH DELAYED MENTAL DEVELOPMENT}

\section{S. Inevatkina A. Agarkova \\ S. Sokolova}

Summary: The article touches upon the issue of changes in modern education of the tool for the formation and assessment of educational results by students. In this regard, the authors reveal the relevance of the formation of communicative universal educational actions. Interpretations of domestic researchers are proposed. The program of the formation of these universal educational actions in younger schoolchildren with mental retardation is described.

Keywords: universal learning activities, communicative universal learning activities, younger students, mental retardation.

\author{
Иневаткина Светлана Евгеньевна \\ К.nсх.н., дочент, Мордовский государственный \\ педагогический университет им. М.Е. Евсевьева (г. \\ Саранск) \\ svetlaj23@mail.ru \\ Агаркова Алина Владимировна \\ Мордовский государственный педагогический \\ университет им. М.Е. Евсевьева (г. Саранск) \\ Соколова София Романовна \\ Мордовский государственный педагогический \\ университет им. М.Е. Евсевьева (2. Саранск)
}

Аннотация: В статье затрагивается вопрос изменения в современном образовании инструмента формирования и оценивания образовательного результата обучающимися. В этой связи, авторами раскрывается актуальность формирования коммуникативных универсальных учебных действий. Предложены трактовки отечественных исследователей. Описывается программа формирования указанных универсальных учебных действий у младших школьников с задержкой психического развития.

Ключевые слова: универсальные учебные действия, коммуникативные универсальные учебные действия, младшие школьники, задержка психического развития.

ные действия выступают в качестве инвариантной основы образовательного и воспитательного процесса. Автор отмечает, что овладение универсальными учебными действиями позволяет школьникам в дальнейшем самостоятельно осваивать новые знания, умения и компетентности [3; 4].

В формате нашей работы предпринята попытка составления программы и методических рекомендаций к ней по формированию коммуникативных универсальных учебных действий у младших школьников с задержкой психического развития. В первую очередь, был определен уровень сформированности коммуникативных универсальных учебных действий у испытуемых указанной категории. Оказалось, что исследуемые универсальные учебные действия, а именно, умение вести диалог, умение учитывать позицию другого, умение осуществлять совместные со сверстником действия, умение логически высказываться сформированы на низком уровне, лишь у единиц испытуемых - на среднем уровне. Высокий уровень сформированности указанных коммуникативных универсальных учебных действий среди младших школьников с задержкой психического развития не встречается. При этом у большинства младших школьников с задержкой психического развития уро-

По мнению О.А. Карабановой универсальные учеб- 
вень сформированности умения использовать различные способы поиска информации находится на среднем и высоком уровнях.

При составлении программы формирования коммуникативных универсальных учебных действий для младших школьников с задержкой психического развития учитывались разработки ученых, которые свидетельствует, что во многом эффективность указанного процесса зависит от имеющихся коммуникативных способностей, которые представляют собой индивидуальные психологические особенности личности, обеспечивающие эффективное взаимодействие и адекватное взаимопонимание между людьми в процессе общения или выполнения совместной деятельности $[1 ; 5]$.

Л.В. Чернецкая в своих работах отмечает, что коммуникативные способности включают в себя три основные составляющие, на которых они основываются и без которых не могут существовать. Первая составляющая коммуникативных способностей - это «область желания», включает в себя потребность в общении, которая и определяет желание ребенка вступить в контакт с окружающими. Без такого желания общение попросту невозможно. Вторая составляющая коммуникативных способностей - «область знания» определяется тем, насколько ребенок имеет представление о нормах и правилах эффективного общения. Это знание формируется также в ходе взаимодействия со взрослыми, которые своим примером показывают ребенку, как вступить в контакт с другим человеком, как поддерживать разговор и завершить его, как разрешить возникающие конфликты. Умение использовать имеющиеся представления об эффективном общении - третья (поведенческая) составляющая коммуникативных способностей - способность к общению «область умений». Она включает в себя умение адресовать сообщение и привлечь к себе внимание собеседника, доброжелательность, аргументированность общения, умение заинтересовать собеседника своим мнением и принять его точку зрения, умение критично относиться к собственному мнению, действиям, высказываниям, умение слушать, эмоционально сопереживать, а также разрешать конфликтные ситуации. Только при наличии всех трех гармонично развитых составляющих можно говорить о наличии у ребенка развитых коммуникативных способностей. Процесс формирования у детей старшего дошкольного возраста коммуникативных способностей, во многом зависит от организации различных видов детской деятельности с использованием разнообразных форм и методов [6, с. 55].

В рамках программы было спланировано 24 занятия, которые проводились в групповой форме, один раз в неделю. Каждое занятие включало в себя три основных этапа: организационный момент, основной этап, подведение итогов. При проведении занятий соблюдался определенный алгоритм. В рамках организационного момента велась работа по установлению контакта между обучающимися и педагогом, педагог работал на создание атмосферы доверия, принятия сверстниками друг друга. На основном этапе решались основные задачи по теме занятия в соответствии с педагогическим замыслом. На этапе подведения итогов основной целью было получение обратной связи от учащихся, которая предполагает эмоциональную и познавательную оценку приобретенных коммуникативных универсальных учебных действий.

Содержание программы представлено в виде шести тематических блоков: «Коммуникативное умение слушать», «Коммуникативное умение выражать свои мысли», «Коммуникативное умение логически высказываться», «Коммуникативное умение вести диалог», «Коммуникативное умение учитывать позицию другого», «Коммуникативное умение осуществлять совместные со сверстником действия». Выбор указанных тематических блоков связан с тем, что формирование коммуникативных универсальных учебных действий позволяет обеспечить основу социального взаимодействия и дальнейшую социальную адаптацию младших школьников с нарушениями речи. Для достижения указанных ориентиров, необходимо умение вести диалог. В свою очередь, для успешности ведения диалога необходимо овладеть умением слушать и умением логически высказываться и выражать свои мысли. Также в диалоге, который является основной формой коммуникативного взаимодействия с окружающими важно уметь учитывать позицию другого, а сам диалог уже является совместным с кем-либо действием.

В рамках первого тематического блока работа была направлена на формирование умения слушать, что предполагает отказ от привычки перебивать. Младшие школьники учатся предоставлять возможность высказаться сверстникам, даже если информация не является для них интересной. Второй тематический блок, нацелен на формирование способности формулировать связанные между собой предложения. Основой третьего тематического блока является отработка умения составлять логически связанные между собой предложения и умение высказываться соответственно конкретному заданию или задаче. Четвертый тематический блок направлен на формирование навыка вступать в диалог со сверстниками и взрослыми, конструктивно поддерживать его. Пятый тематический блок нацелен на формирование у учащихся умения отстаивать собственную точку зрения, при этом слышать и уважать точку зрения собеседника. Также этот этап способствует обучению младших школьников с задержкой психического развития согласовывать собственное поведение с поведением других. Шестой тематический блок способствует формированию у младших школьников с задержкой 
психического развития умения реализовывать какое-либо действие совместно со сверстниками, при этом уметь отстаивать свою точку зрения, но не нарушая границы других.

При составлении программы были выделены три направления: первое - создание мотивации на общение и приобретение коммуникативных универсальных учебных действий; второе - ознакомление младших школьников с задержкой психического развития со средствами и способами общения и формирование у них коммуникативных универсальных учебных действий; третье - творческое применение коммуникативных универсальных учебных действий. Рассмотрим подробнее. Создание мотивации на общение и приобретение коммуникативных универсальных учебных действий является важнейшей предпосылкой успешности всей дальнейшей работы с обучающимися. Мотивация предполагает формирование у испытуемых ценностных основ отношения к действительности, к людям, в сочетании с активным поведением, взаимосвязь осознаваемых и реально действующих мотивов, единство слова и дела. Внимание обращалось, во-первых, на создание положительной мотивации на общение; во-вторых, на создание положительной мотивации на приобретение коммуникативных универсальных учебных действий, что позволит ориентироваться в условиях внешней ситуации общения, планировать содержание акта общения, реализовывать задуманное, подбирать вербальные и невербальные средства, оценивать результативность общения и отвечать адаптацией своего коммуникативного поведения. Содержание работы с учетом второго направления подразумевало ознакомление со сред- ствами (вербальными и невербальными) общения; ознакомление детей со способами общения в зависимости от партнера и коммуникативной ситуации; ознакомление детей со структурой коммуникативной деятельности и способами ориентировки в условиях внешней ситуации общения, планирования содержания акта общения, реализации задуманного, подбора вербальных и невербальных средств, оценки результативности общения и адаптации своего коммуникативного поведения; создание условий для упражнения детей в репродуктивной деятельности. Указанная деятельность реализовывалась непосредственно на занятиях. Творческое применение коммуникативных универсальных учебных действий предполагало использование нестандартных способов коммуникации.

После реализации предложенной программы, с целью выявления динамики уровня сформированности коммуникативных универсальных учебных действий у младших школьников с задержкой психического развития, было проведено дополнительное исследование. Выявлена положительная динамика в формировании изучаемых универсальных учебных действий у испытуемых, а именно, большинство младших школьников с задержкой психического развития продемонстрировали средний уровень сформированности умения вести диалог, умения учитывать позицию другого, умения осуществлять совместные со сверстником действия, умения логически высказываться. Полученный результат позволяет говорить об эффективности предложенной программы, направленной на формирование коммуникативных универсальных учебных действий у младших школьников с задержкой психического развития.

\section{ЛИТЕРАТУРА}

1. Арефьева, 0.М. Особенности формирования коммуникативных универсальных учебных умений младших школьников / 0.М. Арефьева. // Начальная школа плюс до и после. - 2012. - № 2. - С. 74-78.

2. Асмолов, А.Г. Как проектировать универсальные учебные действия в начальной школе: от действия к мысли: пособие для учителя / А.Г. Асмолов. Москва: Просвещение, 2008. - 151 с.

3. Карабанова, 0.А. Формирование универсальных учебных действий учащихся начальной школы / 0.А. Карабанова. // Управление начальной школой. 2009. - № 12. - C. 9-11.

4. Карабанова, 0.А. Что такое универсальные учебные действия и зачем они нужны / 0.А. Карабанова. // Муниципальное образование: инновации и эксперимент. - 2010. - № 2. - С. 11-12.

5. Зайцева, К.П. Формирование коммуникативных способностей младших школьников в учебно-воспитательной деятельности / К.П. Зайцева. // Начальная школа плюс до и после. - 2011. - № 4. - С. 78-83.

6. Рябова, Н.В. Мониторинг уровня сформированности универсальных учебных действий младших школьников / Н.В. Рябова, Е.А. Демидова, О.В. Терлецкая // Гуманитарные науки и образование. - 2018. - Том 9. - № 3. - С. 113-119.

7. Терлецкая, О.В. Особенности изучения коммуникативных универсальных учебных действий младших школьников с ограниченными возможностями здоровья / О.В. Терлецкая, А.С. Крылова // Специальное образование: научно-методический журнал. - 2018. - № 3 (51). - C. $84-94$.

8. Чернецкая, Л.В. Развитие коммуникативных способностей у дошкольников / Л.В. Чернецкая. - Ростов на Дону : Феникс, 2005 - 256 с. 